\title{
Hybridization among wild passionflower species
}

\author{
LÉO DUC HAA CARSON SCHWARTZHAUPT DA CONCEIÇÃO', \\ MARGARETE MAGALHÃES SOUZA ${ }^{2,3}$, GABRIELA DE OLIVEIRA BELO ${ }^{2}$, \\ SHEILA FÉLIX DOS SANTOS ${ }^{2}$ and JÔSIE CLOVIANE OLIVEIRA DE FREITAS ${ }^{2}$
}

(received: October 14, 2010; accepted: April 28, 2011)

\begin{abstract}
Hybridization among wild passionflower species). Passion fruits are appreciated for their ornamental value, since their flowers are showy and display a wide variety of colors. In addition, many hybrids have been produced and used in other countries. The genotypes used in selection of plants with ornamental characteristics are hybrid progenies which are used in various crossing strategies. Thus, the aim of this work was to obtain interspecific hybrids, perform backcrossing and obtain progenies from crossings between hybrids, and to determine the reproductive compatibility between the progenitors involved. The percentage of fertilized flowers, germination, and the number of fruits, seeds and plants obtained through crossing were recorded. A series of 374 crossings involved seven species and two hybrids. Crossings such as Passiflora gibertii N. E. Brown vs. P. kermesina Link \& Otto and P. gibertii vs. P. alata Curtis did not produce seeds. The largest percentage of fertilized flowers (86\%) was recorded for the crossing $P$. gardneri Mast.vs. P. cincinnata Mast.; yet, the seeds produced did not show endosperm. Interspecific hybrids were obtained from the crossings $P$. gardneri vs. $P$. alata, $P$. watsoniana Mast.vs. $P$. alata, $P$. watsoniana vs. P. gardneri and $P$. gardneri vs. $P$. gibertii. Seeds generated from backcrossings involving the hybrids $P$. sublanceolata (sin. P. palmeri var. sublanceolata (Killip) J. M. MacDougal) vs. P. foetida var. foetida L. (HD13-133 and HD13-141) and $\mathrm{F}_{2}$ reached high germination percentages.
\end{abstract}

Key words - interspecific crossing, ornamental plants, Passiflora, seed germination

RESUMO - (Hibridação entre espécies silvestres de passifloras). As passifloras são apreciadas por seu valor ornamental, pois suas flores são vistosas e com enorme diversidade de cores, e muitos híbridos têm sido produzidos e utilizados em outros países. As fontes para seleção de plantas com características ornamentais são progênies híbridas utilizadas em variadas estratégias de cruzamentos. Assim, os objetivos do trabalho foram obter híbridos interespecíficos, realizar retrocruzamentos e obter progênies de cruzamentos entre híbridos e, desta forma, verificar a compatibilidade reprodutiva entre os genitores envolvidos. Foram registrados o percentual de flores fertilizadas e de germinação, além do número de frutos, de sementes e de plantas obtidos por cruzamento. Realizaram-se 374 hibridações envolvendo sete espécies e dois híbridos. Cruzamentos como Passiflora gibertii N. E. Brown vs. P. kermesina Link \& Otto e P. gibertii vs. P. alata Curtis produziram frutos que não formaram sementes. Para o cruzamento entre $P$. gardneri Mast. vs. P. cincinnata Mast. registrou-se o maior percentual de flores fertilizadas (86\%), porém as sementes produzidas não apresentaram endosperma. Foram obtidos híbridos interespecíficos dos cruzamentos $P$. gardneri vs. P. alata, P. watsoniana Mast. vs. P. alata, P. watsoniana vs. P. gardneri e P. gardneri vs. P. gibertii. Sementes geradas de retrocruzamentos envolvendo os híbridos P. sublanceolata (sin. P. palmeri var. sublanceolata (Killip) J. M. MacDougal) vs. P. foetida var. foetida (HD13-133 e HD13-141) e $\mathrm{F}_{2}$ atingiram elevados valores percentuais de germinação.

Palavras-chave - cruzamentos interespecíficos, germinação de sementes, Passiflora, plantas ornamentais

\section{Introduction}

Interspecific hybridization in the genus Passiflora L. has been used as a strategy intended to obtain genotypes with interesting characteristics to the ornamental plant

1. Empresa Brasileira de Pesquisa Agropecuária, Embrapa Cerrados, Rodovia Brasília-Fortaleza, BR020 km 18, 73310-970 Planaltina, DF, Brazil.

2. Universidade Estadual de Santa Cruz, Departamento de Ciências Biológicas, Pavilhão Jorge Amado, Rodovia Ilhéus-Itabuna, km 16, 45662-900 Ilhéus, BA, Brazil.

3. Corresponding author: souzamagg@yahoo.com.br market. Some hybrids are already known, such as $P$. 'Sunburt', with orange flowers originated from the crossing between $P$. gilbertiana J.M. MacDougal and P. jorullensis H. B. K (Vanderplank 2000). Species with ornamental attributes, such as $P$. alata Curtis and $P$. caerulea L., among others, have been used in other countries for the creation of several hybrids. Passiflora 'Albo-nigra', $P$. 'Amethyst', $P$. 'Star of Bristol', $P$. 'Star of Kingston', and other hybrids are commercialized and used in the decoration of American and European glasshouses (Vanderplank 2000, Ulmer \& MacDougal 2004). 
In Brazil, the center of origin for at least one third of the Passiflora species (Ganga et al. 2004), the potential for ornamental plants is almost unexplored (Abreu et al. 2009). The wild species are considered proper for use in breeding programs aiming to produce ornamental Passiflora because of their exuberant foliage, attractive, colorful and exotic flowers, and a high number of flowers (Abreu et al. 2009). The sources of variability for selection of genotypes are progenies obtained from interspecific hybridization and backcrossing. Thus, the aim of this work was to obtain interspecific $\mathrm{F}_{1}$ hybrids, perform backcrossings and obtain progenies from crossings between hybrids in order to determine the reproductive compatibility between involved progenitors; in addition, it aims at a future selection of plants with characteristics of interest to the ornamental plant market.

\section{Material and methods}

Crossings were performed from November 2006 to August 2008 and comprised accessions of the Germplasm Active Bank of Passionflowers from the Universidade Estadual de Santa Cruz, where seven species of the subgenus Passiflora L. were obtained: $P$. alata Curtis, P. cincinnata Mast., P. gardneri Mast., P. gibertii N. E. Brown, P. kermesina Link \& Otto, $P$. sublanceolata (Killip) J. M. MacDougal (sin. P. palmeri var. sublanceolata Killip), P. watsoniana Mast., and the hybrids HD13 = 133 and HD13-141 (Passiflora sublanceolata vs. . . foetida var. foetida L.). A total of 374 crossings were carried out, among interspecific hybridizations, backcrossings, and the obtention of $\mathrm{F}_{2}$ progenies (table 1). Controlled pollination was conducted according to the following procedure. Flower buds were protected using corn paper bags $(10 \mathrm{~cm} \times 20 \mathrm{~cm})$ in pollen donor and receptor plants at pre-anthesis. On the following day, the recipient flowers were emasculated before flower opening. Pollination was held one hour after flowers

Table 1. Analysis of controlled crossings involving Passiflora L. ( $\mathrm{Set}=$ fruit set percentage; Ger = germination; Pol = number of pollinations performed; $\mathrm{F}=$ number of fruits; $\mathrm{S}=$ seeds; $\mathrm{P}=$ plants obtained).

\begin{tabular}{|c|c|c|c|c|c|c|c|c|c|c|}
\hline \multirow{2}{*}{$\begin{array}{l}\text { Crossings } \\
\text { P. alata vs. P. watsoniana }\end{array}$} & \multirow{2}{*}{$\begin{array}{c}\text { Pol } \\
18\end{array}$} & \multirow{2}{*}{$\begin{array}{r}\text { Set } \\
(\%)\end{array}$} & \multicolumn{2}{|c|}{$\begin{array}{c}\chi^{2} \\
\text { Set }\end{array}$} & \multirow{2}{*}{$\begin{array}{l}\mathrm{F} \\
4\end{array}$} & \multirow{2}{*}{$\begin{array}{c}\mathrm{S} \\
568\end{array}$} & \multirow{2}{*}{$\begin{array}{r}\text { Ger } \\
(\%) \\
0\end{array}$} & \multicolumn{2}{|c|}{$\begin{array}{c}\chi^{2} \\
\text { Ger }\end{array}$} & \multirow{2}{*}{$\begin{array}{l}\mathrm{P} \\
-\end{array}$} \\
\hline & & & 53.3 & $*$ & & & & 495.2 & $*$ & \\
\hline P. watsoniana vs. P. alata & 13 & 31 & 44.6 & $*$ & 4 & 264 & 18 & 304.1 & $*$ & 37 \\
\hline P. gardneri vs. P. alata & 30 & 83 & 16.9 & $* \dagger$ & 9 & 839 & 3 & 460.2 & $*$ & 22 \\
\hline P. alata vs. $P$. gardneri & 10 & 0 & 171.7 & $*$ & - & - & - & - & & - \\
\hline P. gardneri vs. $P$. cincinnata & 21 & 86 & 22.4 & $* \dagger$ & 7 & 479 & 0 & 495.2 & $*$ & - \\
\hline P. cincinnata vs. $P$. gardneri & 21 & 0 & 100.0 & $*$ & - & - & - & - & & - \\
\hline P. gardneri vs. P. gibertii & 14 & 57 & 1.7 & $\mathrm{~ns}^{\dagger}$ & 8 & 468 & 12 & 362.7 & $*$ & 31 \\
\hline P. gibertii vs. P. gardneri & 3 & 0 & 100.0 & $*$ & - & - & - & - & & - \\
\hline P. gibertii vs. $P$. alata & 32 & 50 & 7.5 & $*$ & 12 & 0 & - & - & & - \\
\hline P. alata vs. P. gibertii & 10 & 0 & 171.7 & $*$ & - & - & - & - & & - \\
\hline P. gibertii vs. P. kermesina & 7 & 71 & 2.6 & $\mathrm{~ns}^{\dagger}$ & 5 & 0 & - & - & & - \\
\hline P. kermesina vs. P. gibertii & 1 & 0 & 100.0 & $*$ & - & - & - & - & & - \\
\hline P. gibertii vs. $P$. watsoniana & 42 & 40 & 23.1 & $*$ & 8 & 15 & 0 & 495.2 & $*$ & - \\
\hline P. watsoniana vs. $P$. gibertii & 9 & 0 & 100.0 & $*$ & - & - & - & - & & - \\
\hline P. sublanceolata vs. $P$. cincinnata & 17 & 24 & 66.1 & $*$ & 4 & 0 & - & - & & - \\
\hline P. cincinnata vs. $P$. sublanceolata & 2 & 0 & 100.0 & $*$ & - & - & - & - & & - \\
\hline P. watsoniana vs. $P$. cincinnata & 67 & 16 & 95.8 & $*$ & 6 & 109 & 0 & 495.2 & $*$ & - \\
\hline P. cincinnata vs. $P$. watsoniana & 9 & 0 & 171.7 & $*$ & - & - & - & - & & - \\
\hline P. watsoniana vs. P. gardneri & 5 & 60 & 0.4 & $\mathrm{~ns}^{\dagger}$ & 3 & 284 & 32 & 187.5 & * & 51 \\
\hline P. gardneri vs. P. watsoniana & 5 & 0 & 100.0 & $*$ & - & - & - & - & & - \\
\hline P. sublanceolata vs. HD13-133 & 7 & 43 & 17.5 & $*$ & 3 & 26 & 68 & 16.5 & $*$ & 13 \\
\hline P. sublanceolata vs. HD13-141 & 14 & 21 & 76.6 & $*$ & 3 & 83 & 83 & 0.0 & $\mathrm{~ns}^{*}$ & 30 \\
\hline HD13-133 vs. HD13-141 & 8 & 38 & 27.3 & * & 3 & 42 & 58 & 45.4 & $*$ & 14 \\
\hline HD13-141 vs. HD13-133 & 9 & 44 & 15.9 & $*$ & 4 & 65 & 78 & 1.9 & $\mathrm{~ns}^{*}$ & 25 \\
\hline
\end{tabular}

*: Significance level $P<0.05$; ns: not significant $P>0.05 ;{ }^{\dagger}$ : set $\geq 63.2 \%$ (Aular et al. 2005); ${ }^{*}$ : germination $\geq 83.2 \%$ (Ferreira et al. 2005); -: not survived. 
opened, so that flowers with non-deflective styles and not receptive to pollen were avoided. The flowers were protected after the completion of manual pollination. After five days, abortion of the flower bud or start of fruit development were observed. The fruits were collected between 40-60 days after pollination.

The seeds were washed and dried at room temperature and stored at $5{ }^{\circ} \mathrm{C}$. For germination, seeds were treated in sodium hypochlorite ( $2.5 \%$ active chlorine). Part of the seed coat was removed and then the seeds were placed on filter paper and daily moistened with a gibberellic acid solution (100 $\mathrm{mg} \mathrm{L}^{-1}$ ). Data on the percentage of fruit set (developing fruits five days after pollination), number of fruits, seeds, germination percentage and the number of surviving plants were obtained. Differences in flowering time and the need to use the seeds soon after collection, in order to prevent losses in germination capacity, precluded establishing an appropriate experimental design. Thus the $\chi^{2}$ test $(P<0.05)$ was used for statistical analysis. Fruit set percentage of $63 \%$ (expected value) was therefore used as a parameter, as reported by Aular et al. (2004), for interspecific artificial hybridization in $P$. cincinnata. An average value of $83.2 \%$ was found by Ferreira et al. (2005) in a pre-germination treatment with gibberellic acid, and the removal of aril in $P$. alata was performed for germination.

\section{Results}

Fruit set in interspecific hybridizations ranged between $0 \%$ and $86 \%$ (table 1). All hybridizations involving backcrossings and H13-133 and HD13-141 generated progenies, and the values found for fruit set ranged between $21 \%$ and $44 \%$. Interspecific hybrids were obtained from the crossings $P$. gardneri vs. P. alata, $P$. watsoniana vs. P. alata, $P$. watsoniana vs. P. gardneri and $P$. gardneri vs. $P$. gibertii, generating $22,37,51$ and 31 plants, respectively. The crossings $P$. sublanceolata vs. $P$. cincinnata, $P$. gibertii vs. $P$. kermesina and $P$. gibertii vs. $P$. alata produced fruit, but not seeds. The seeds produced through the crossings $P$. alata vs. $P$. watsoniana, $P$. gardneri vs. $P$. cincinnata, $P$. gibertii vs. $P$. watsoniana and $P$. watsoniana vs. $P$. cincinnata did not germinate (table 1). Only five crosses had fruit set similar to or higher than expected, according to the reference value used in the chi-square test. In only two crosses the germination percentage observed reached the expected value.

\section{Discussion}

Despite the large number of ornamental hybrids produced, recorded and commercialized in many countries (Vanderplank 2000, Ulmer \& MacDougal
2004), there are pre- and post-zygotic barriers in interspecific crosses involving the genus Passiflora. For most species of the subgenus Passiflora L. the chromosome number is $2 \mathrm{n}=18$ (Souza et al. 2008). In the present study, the interspecific crosses involving the species $P$. sublanceolata $(2 \mathrm{n}=22$; Abreu 2008) and $P$. cincinnata $(2 \mathrm{n}=18$; Guerra 1986$)$ failed probably due to this chromosome number difference. The progenitor species that originated the hybrids UESC HD13, $P$. sublanceolata and $P$. foetida var. foetida have the same chromosome number $(2 \mathrm{n}=22$; Abreu 2008) and belong to the same section, Dysosmia DC., (MacDougal $\&$ Feuillet 2004). Promising results were obtained in crossings between $P$. edulis f. flavicarpa O. Deg. and P. setacea, P. coccinea and P. glandulosa Cav., all with $2 \mathrm{n}=18$ (Souza et al. 2008), and reciprocal crossings (Junqueira et al. 2005).

Self-incompatibility has been studied in species of the genus Passiflora L., such as $P$. quadrangularis L., P. cincinnata (Howell 1976), P. edulis f. flavicarpa (Ruggiero 1976) and P. edulis Sims (Bruckner et al. 1995, Suassuna et al. 2003). Self-incompatibility reactions may be responsible for failure in interspecific crossings. Kimura et al. (2002) demonstrated the existence of $S$ gene alleles common to two species of the genus Brassica, which have identical self-incompatibility reaction, except for interspecific hybridization. Incompatible species (IS) often show unilateral interspecific incompatibility to selfcompatible species (SS): the pollen tube of IS grows into the style of SS, but the opposite does not occur. There are also reports of unilateral interspecific incompatibility in the genus Lycopersicon C. H. Müll., Nicotiana L., Capsicum L. and Petunia Juss. (Onus \& Pickrsgill 2004). The crossings $P$. watsoniana vs. P. gardneri and $P$. gardneri vs. $P$. gibertii and their reciprocals showed results that suggest the occurrence of that phenomenon. More detailed studies on individual species and their crossings are therefore needed to confirm this unilateral incompatibility hypothesis.

Another possible barrier regarding interspecific hybridization is related to the combination nucleuscytoplasm (Nimura etal.2003). Negative interactions may endanger the embryo or cause failure in the development of the endosperm. In this study, the crossing P. gardneri vs $P$. cincinnata with higher fruit set percentage $(86 \%)$ produced hundreds of seeds; however $100 \%$ of the seeds did not contain endosperm. The hybridizations $P$. gibertii vs. $P$. kermesina and $P$. gibertii vs. $P$. alata produced fruits, however no seeds were formed (table 1). Similar results were found in P. caerulea vs. P. edulis $\mathrm{f}$. flavicarpa, in which fruits containing seeds were rarely 
generated. When $P$. edulis f. flavicarpa was used as the male progenitor, fruits with many fertile $\mathrm{F}_{1}$ seeds were produced (Junqueira et al. 2005).

Except for P. watsoniana vs. P. alata (31\%), three in five hybridizations with fruit set percentage equal to or above $63.2 \%$, according to the chi-square test, were interspecific crosses capable of generating plants. All interspecific hybrids obtained in this study were confirmed using the molecular technique RAPD (Conceição et al. 2011). The high percentage of germination was decisive in the production of plants on backcrossings and crossings among hybrids. Although the crossings $P$. sublanceolata vs. HD13-133 and HD13-133 vs. HD13-141 remained below the expected value of $83.2 \%$ (Ferreira et al. 2005), they were able to produce progeny.

Acknowledgements - Research supported by Fapesb (Fundação de Amparo a Pesquisa do Estado da Bahia), CNPq (Conselho Nacional de Desenvolvimento Científico e Tecnológico) and Uesc (Universidade Estadual de Santa Cruz).

\section{References}

ABREU, P.P. 2008. Relações citogenéticas e caracterização fisiológica em genitores Passiflora foetida var. foetida $\times$ Passiflora palmeri var. sublanceolata e híbridos interespecíficos $F_{1}$ ornamentais. Dissertação de mestrado, Universidade Estadual de Santa Cruz, Ilhéus.

ABREU, P.P., SOUZA, M.M., SANTOS, E.A., PIRES, M.V., PIRES, M.M. \& ALMEIDA, A.F. 2009. Passion flower hybrids and their use in the ornamental plant market: perspectives for sustainable development with emphasis on Brazil. Euphytica 166:307-315.

AULAR, J., PARÉS, J., IADE, P. \& RODRÍGUEZ, Y. 2004. Crecimiento reproductivo de Passiflora cincinnata Mast. Biagro 16:205-212.

BRUCKNER, C.H., CASALI, V.W.D., MORAES, C.F., REGAZI, A.J. \& SILVA, E.A. 1995. Self-incompatibility in passion fruit (Passiflora edulis Sims). Acta Horticulturae 370:45-57.

CONCEIÇÃO, L.D.H.C.S, BELO, G.O., SOUZA, M.M., SANTOS, S.F., CERQUEIRA-SILVA, C.B.M. \& CORRÊA, R.X. 2011. Confirmation of cross-fertilization using molecular markers in ornamental passion flower hybrids. Genetics and Molecular Research 10:47-52.

FERREIRA, G., OLIVEIRA, A., RODRIGUES, J.D., DIAS, G.B., ALESSANDRA MARIA DETONI, A.M., TESSER, S.M. \& ANTUNES, A.M. 2005. Efeito de arilo na germinação de sementes de Passiflora alata Curtis em diferentes substratos e submetidas a tratamentos com giberelina. Revista Brasileira de Fruticultura 27:277280.
GANGA, R.M.D., RUGGIERO, C., LEMOS, E.G.M., GRILI, G.V.G., GONÇALVES, M.M., CHAGAS, E.A. \& WICKERT, E. 2004. Diversidade genética em maracujazeiro-amarelo utilizando marcadores moleculares AFLP. Revista Brasileira de Fruticultura 26:494-498.

GUERRA, M.S. 1986. Citogenética de angiospermas coletadas em Pernambuco. Revista Brasileira de Genética 9:21-40.

HOWELL, C.W. 1976. Edible fruited Passiflora adapted to south Florida growing conditions. Proceedings of the Florida State Horticultural Society 89:236-238.

JUNQUEIRA, N.T.V., BRAGA, M.F., FALEIRO, F.G., PEIXOTO, J.R. \& BERNACCI, L.C. 2005. Potencial de espécies silvestres de maracujazeiro como fonte de resistência a doenças. In Maracujá: germoplasma e melhoramento genético (F.G. Faleiro, N.T.V. Junqueira \& M.F. Braga, eds.). Embrapa Cerrados, Planaltina, p.54-78.

KIMURA, R., SATO, K., FUJIMOTO, R. \& NISHIO, T. 2002. Recognition specificity of self-incompatibility maintained after the divergence of Brassica oleracea and Brassica rapa. The Plant Journal 29:215-223.

MACDOUGAL, J.M. \& FEUILLET, C. 2004. Systematics. In Passiflora: passionflowers of the world (T. Ulmer \& J.M. MacDougal, eds.). Timber Press, Portland, p.2731.

NIMURA, M., KATO, J., MII, M. \& MORIOKA, K. 2003. Unilateral compatibility and genotypic difference in crossability in interspecific hybridization between Dianthus caryophyllus L. and Dianthus japonicus Thunb. Theoretical and Applied Genetics 106:11641170.

ONUS, A.N. \& PICKERSGILL, A. 2004. Unilateral incompatibility in Capsicum (Solanaceae): occurrence and taxonomic distribution. Annals of Botany 94:289-295.

RUGGIERO, C., LAM-SANCHEZ, A. \& BANZATTO, D.A. 1976. Studies on natural and controlled pollination in yellow passion fruit (Passiflora edulis f. flavicarpa Deg.). Acta Horticulturae 57:121-124.

SOUZA, M.M., PEREIRA, T.N.S. \& VIEIRA, M.L.C. 2008. Cytogenetic studies in some species of Passiflora L. (Passifloraceae): a review emphasizing Brazilian species. Brazilian Archives of Biology and Technology 51:247-258.

SUASSUNA, T.M.F., BRUCKNER, C.H., CARVALHO, C.R. \& BORÉM, A. 2003. Self-incompatibility in passionfruit: evidence of gametophytic-sporophytic control. Theoretical and Applied Genetics 106:298302.

UlMER, T. \& MACDOUGAL, J.M. 2004. Passiflora: passionflowers of the world. Timber Press, Portland.

VANDERPLANK, J. 2000. Passion flowers. The MIT Press, Cambridge. 